Safarina Malik • Herawati Sudoyo - Tedjo Sasmono

Sunaryana Winata • I Nyoman Arhya

Patcharin Pramoonjago • Wayan Sudana

Sangkot Marzuki

\title{
Nonsyndromic sensorineural deafness associated with the A1555G mutation in the mitochondrial small subunit ribosomal RNA in a Balinese family
}

Received: July 12, 2002 / Accepted: November 22, 2002

\begin{abstract}
Sensorineural deafness associated with increased sensitivity to aminoglycoside antibiotics as the consequence of an A1555G mutation in the mitochondrial DNA (mtDNA) in a highly conserved region of the small (12S) rRNA gene has been reported in Caucasian, Chinese, and Japanese individuals. We report here a large family of Balinese Indonesian origin with progressive/congenital sensorineural deafness who carry the A1555G mutation. The pedigree shows a generally maternal inheritance pattern with some exceptions, which is the result of an unusual multiple entry of the mutation into the pedigree. A complete mtDNA genome sequence from three Balinese individuals revealed a relatively large number of singlenucleotide polymorphisms (20) not previously reported, and confirmed the genetic distance of Southeast Asian populations from those of Caucasians and Japanese. The biochemical expression of the A $1555 \mathrm{G}$ mutation under the influence of this mtDNA background was investigated. Examination of respiratory enzyme activities showed a significant decrease in respiratory complex I activity, particularly in symptomatic family members.
\end{abstract}

S. Malik $\cdot$ H. Sudoyo $\cdot$ T. Sasmono $\cdot$ P. Pramoonjago

S. Marzuki $(\square)$

Eijkman Institute for Molecular Biology, JI. Diponegoro 69, Jakarta 10430, Indonesia

Tel. +62-21-3148694; Fax +62-21-3147982

e-mail smarzuki@eijkman.go.id

S. Winata

Department of Microscopic Anatomy, University of Udayana,

Denpasar, Indonesia

I.N. Arhya

Department of Biochemistry, University of Udayana, Denpasar, Indonesia

W. Sudana

Department of Ear, Nose, and Throat, University of Udayana,

Denpasar, Indonesia
Key words Sensorineural deafness - Mitochondrial DNA · Haplogroup $\cdot$ D-loop $\cdot$ Aminoglycosides

\section{Introduction}

Mutations in the mitochondrial DNA (mtDNA) have been reported to be associated with sensorineural deafness. The most common of these mutations are the $\mathrm{A} 3243 \mathrm{G}$ mutation affecting tRNA $^{\text {Leu }}$ and the A1555G base substitution in a highly conserved region of the small (12S) rRNA gene. The latter affects a site in which aminoglycoside resistance mutations have been described in other species (De Stasio et al. 1989; Etzold et al. 1987; Montandon et al. 1986), in line with the observation that the phenotypic expression of the mtDNA A1555G mutation is precipitated by exposure to aminoglycoside antibiotics, although such exposure is not always essential. Sensorineural deafness associated with increased sensitivity to aminoglycoside antibiotics has been reported in a number of Caucasian, Chinese, and Japanese individuals and pedigrees (Prezant et al. 1993; Matthijs et al. 1996; Usami et al. 1997; Pandya et al. 1997; Estivill et al. 1998).

Here we report a seven-generation Balinese family with progressive non-syndromic deafness associated with the mtDNA A1555G mutation, the first sensorineural deafness case reported in the Southeast Asian region, which, at first inspection, presented itself with a confusing pattern of inheritance. We have studied this family in detail to investigate (1) whether the exception to the maternal pattern of inheritance has arisen because of multiple entries of the mtDNA A1555G mutation into the pedigree, (2) the genetic characteristics of the expression of the mutation as non-aminoglycoside-induced sensorineural deafness, and (3) the respiratory enzyme deficiencies as the biochemical expression of the mtDNA mutation. We have sequenced the mtDNA of two members of the family and one normal control, and we report the first total mtDNA sequences of island Southeast Asians, demonstrating a relatively large number (20) of previously unreported single-nucleotide polymorphisms (SNPs). 


\section{Patients and methods}

Patients and fibroblast culture

The family members were first examined in Singaraja, on the north coast of the island of Bali in Indonesia. Other family members were then traced in Denpasar, the capital city, $100 \mathrm{~km}$ south of Singaraja. Twenty-six subjects were analyzed both genetically and clinically. During the examination, blood samples $(10 \mathrm{ml})$, skin biopsies, and hair root samples were taken from certain members of the family with informed consent as part of the diagnostic workup of the patients. These samples were kept at $4^{\circ} \mathrm{C}$ for about $24 \mathrm{~h}$ before being transported to Jakarta.

The procedures for skin biopsy and the generation of fibroblast cell lines are as previously reported (Malik et al. 2000). The fibroblast cell lines used were derived from two members of the pedigree: one deaf (EISi-IV-78) and one hearing (EISi-V-46) member. One fibroblast cell line derived from a normal individual was used as a control (EIN2-95; Malik et al. 2000).

\section{DNA isolation and analysis}

Total DNA was extracted from blood and fibroblasts as described elsewhere (Lertrit et al. 1992). A 551-bp fragment of the mtDNA within the 12S rRNA gene between nucleotide (nt) 1231 and nt 1782 was polymerase chain reaction (PCR) amplified using primer pair L1231 (5'-AACCTC ACCACCTCTTGCTCA-3') and H1782 (5'-CTATAT CTATTGCGCCAGGTTTCA-3') in a programmable thermal cycler (Perkin Elmer 9700 GeneAmp System; ABI-PE, Norwalk, CT, USA). The PCR amplification was carried out for 30 cycles of denaturation at $95^{\circ} \mathrm{C}$ for $1 \mathrm{~min}\left(95^{\circ} \mathrm{C}\right.$ for $5 \mathrm{~min}$ at first cycle), annealing at $56^{\circ} \mathrm{C}$ for $1 \mathrm{~min} 30 \mathrm{~s}$, and extension at $72^{\circ} \mathrm{C}$ for $2 \mathrm{~min} 30 \mathrm{~s}\left(72^{\circ} \mathrm{C}\right.$ for $5 \mathrm{~min}$ for final extension). The amplified DNA was then digested with Alw26I restriction endonuclease (Promega, Madison, WI, USA) (Pandya et al. 1997), and electrophoresed on a $2 \%$ agarose gel (Sigma, St. Louis, MO, USA). The A1555G base substitution was detected as the loss of an Alw26I restriction site.

Five restriction endonucleases, which define eight polymorphic sites (10394 DdeI, 10397 AluI, 16517 HaeIII, 12408 HincII, 12408 HpaI, 13259 HincII, 13262 AluI, 663 HaeIII), were used for haplotype analysis of the mtDNA using the procedure essentially as in Malik et al. (2002). Together with the COII/tRNA ${ }^{\text {Lys }}$ 9-bp deletion, these polymorphic sites characterize the most common haplogroups associated with Asian populations (Torroni et al. 1993).

For the sequencing of the total mtDNA, overlapping fragments were amplified by PCR essentially as described in Marzuki et al. (1991), directly sequenced (as in Sudoyo et al. 2002) using 60 internal primers, and compared with the previously published sequence (Anderson et al. 1981; Andrews et al. 1999).
Isolation of mitochondria from fibroblast cells and measurement of respiratory enzyme activities

Mitochondria were isolated from fibroblast cells by a modification of the method described in Trounce et al. (1996). The measurements of the mitochondrial respiratory enzyme activities were carried out spectrophotometrically with a dual beam UV-visual spectrophotometer (U3300, Hitachi, Tokyo, Japan). NADH-cytochrome $c$ oxidoreductase (EC1.6.5.3 plus EC1.10.2.2) and succinate-cytochrome $c$ oxidoreductase (EC1.3.5.1 plus EC1.10.2.2) activities were assayed as described by Byrne et al. (1988). The NADHcytochrome $c$ oxidoreductase activity of the isolated fibroblast mitochondria was assayed in triplicate at $37^{\circ} \mathrm{C}$ using $50 \mu \mathrm{g}$ of mitochondrial protein in a $1-\mathrm{ml}$ reaction mixture containing $25 \mathrm{mM}$ potassium phosphate and $5 \mathrm{mM}$ magnesium chloride at $\mathrm{pH}$ 7.2. The reaction was initiated by the addition of $150 \mu \mathrm{M} \mathrm{NADH}$, and the rate of the enzyme activity was determined by following the antimycin Asensitive reduction of cytochrome $c$ by NADH at $550 \mathrm{~nm}$. The succinate-cytochrome $c$ oxidoreductase activity was assayed at $37^{\circ} \mathrm{C}$ in triplicate with the addition of $50 \mu \mathrm{g}$ of mitochondrial protein into a 1-ml reaction mixture, as noted earlier, by measuring the antimycin A-sensitive reduction of cytochrome $c$ by $20 \mathrm{mM}$ succinate.

\section{Results}

The Balinese family with maternally inherited congenital sensorineural deafness

The large family lived in a village in the Singaraja region of Bali, and the pedigree constructed is shown in Fig. 1. Deafness can be traced back for six generations of the 213 family members and was confirmed by audiological examinations with a type D audiometer (Minaty Medical Science, Osaka, Japan). Although the pedigree did not show a typical pattern of inheritance, certain branches suggested the possibility of a maternal mode. At the time of the study, there were 188 living members, of which 26 members were available for clinical examination. Most of these members exhibited signs of sensorineural deafness, with clinical manifestation varying from mild to total deafness. The age of onset was found to vary from 2 to 10 years, and extensive interviews established that the Balinese family has no history of exposure to aminoglycoside antibiotics. Local health authorities confirmed that streptomycin has not been used in the region for at least 20 years, and kanamycin and neomycin were only introduced recently and were far too expensive for the local population. Neurological examination performed on 12 deaf members excluded other neurological involvement.

MtDNA mutation underlying the congenital sensorineural deafness in the Balinese family

The most common mtDNA mutation associated with sensorineural deafness is the $\mathrm{A} 1555 \mathrm{G}$ mutation in the $12 \mathrm{~S}$ rRNA 
Fig. 1. A six-generation Balinese family with nonsyndromic sensorineural deafness. The pedigree of the Balinese family consists of 213 (188 living) members, of which a total of 41 (35 living) are affected. $\square \mathbf{\square}$, Male; $\bigcirc \bullet$, female; - $\bullet$, affected; $\square \bigcirc$, asymptomatic; /, deceased. Two deaf members of the family $(\boldsymbol{\nabla})$ were examined for the mtDNA A1555G mutation by direct sequencing, and the existence of this mutation was subsequently examined in 24 other members $(\nabla)$ by polymerase chain reaction - restriction fragment length polymorphism. Branches shaded are those of non-maternally inherited deaf members. All the fifth-generation members were older than 5 years of age. The sixth-generation members were between 1 and 5 years of age, and thus not included in the present study

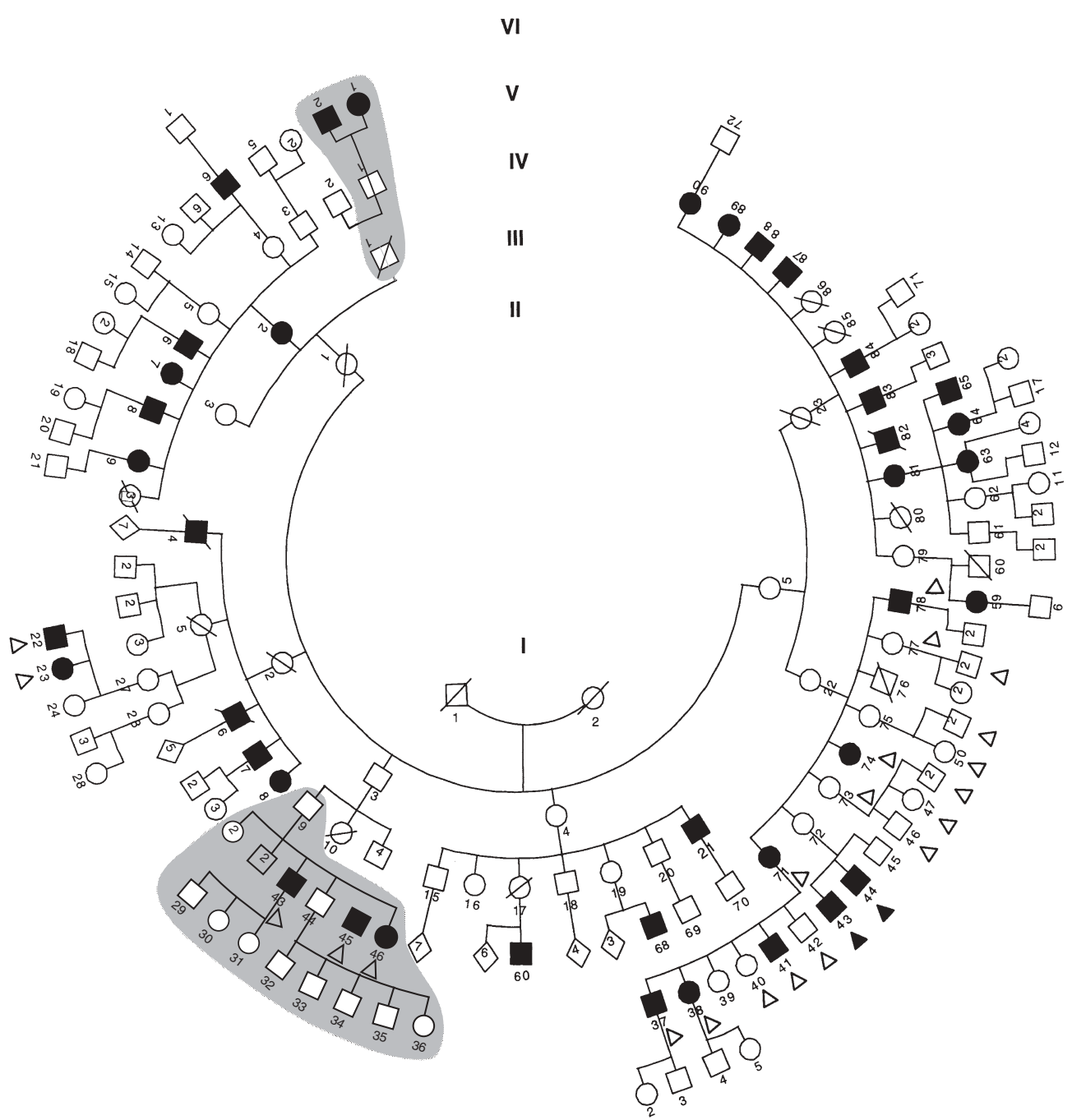

gene. Two deaf members of the family (EISi-V-43 and EISi$\mathrm{V}-44$ ) were examined for this mutation, and direct sequencing of a PCR-amplified fragment of the mtDNA revealed the A1555G mutation (Fig. 2a). The presence of this mutation in a homoplasmic manner was subsequently demonstrated by using a PCR-based restriction fragment length polymorphism (RFLP) strategy in 24 other members examined (Fig. 2b).

The finding of the mtDNA A1555G mutation is an enigma in terms of the pattern of inheritance observed. Deaf family members could also be identified along the nonmaternal III-1 and III-9 lines of the pedigree. We did not examine the descendants of III-1, because we did not have access to the wife of IV-1 or the two children of this small branch; the wife of IV-1 was deaf and the deafness observed in the two children was most likely to be inherited through their mother. More interesting is the nonmaternal branch started with male member III-9, which is much larger in size and had three deaf members; the wife of III-9 was not deaf. We have examined the mtDNA of family members IV-43, IV-45, and IV-46 of this branch and have found the A1555G mutation there also. The hearing wife of
III-9 who was not available for the study, therefore, must have carried the mtDNA A1555G mutation.

To examine whether the mtDNA background associated with the main A1555G mutation in the large family is different from the newly introduced one through the wife of III-9, we investigated the haplotypes of the mtDNA belonging to descendants of II-2 (V-22 and V-23), II-5 (IV-78 and V-43), and II-3 (IV-43 and IV-45) by highresolution PCR-RFLP at several diagnostic polymorphic sites in the mtDNA (Torroni et al. 1993). All six mtDNAs examined were found to be of haplogroup B (absence of 10394 DdeI and 10397 AluI sites; gain of 16517 HaeIII site and the 9-bp deletion; Torroni et al. 1993; data not shown).

To obtain a more detailed picture of the mtDNA background associated with the two entries of the A1555G mutation, we sequenced the highly polymorphic hypervariable region I and II of the mtDNA D-loop of the large family (represented by V-43) and that introduced by the wife of III-9 (represented by IV-45). The two mtDNAs carry 13 and 12 SNPs when compared with the Cambridge reference sequence (Table 1; Anderson et al. 1981; Andrews et al. 


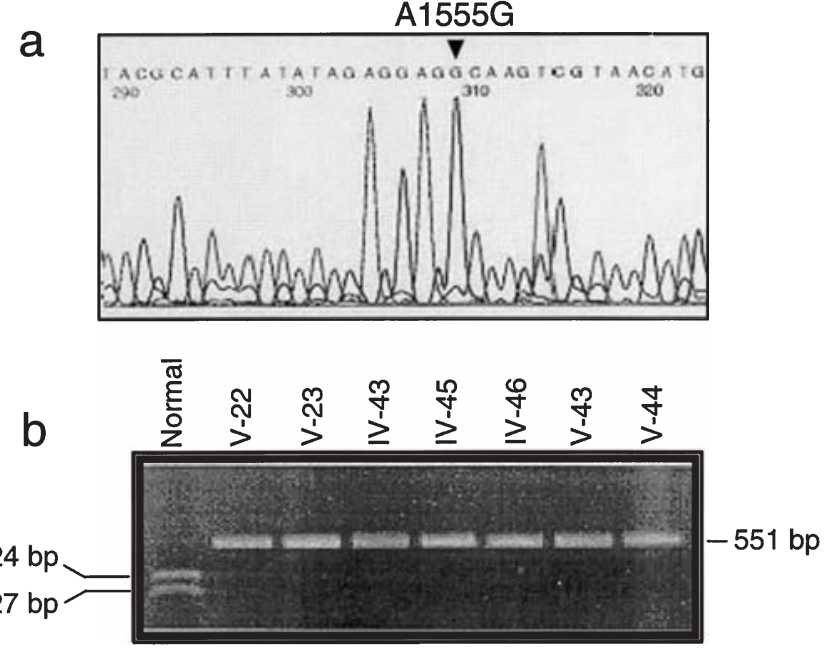

Fig. 2a,b. Detection of the MtDNA A1555G mutation in the Balinese family. a A 1451-bp fragment of the mitochondrial DNA (mtDNA) of family members V-43 and V-44, containing the $12 \mathrm{~S}$ rRNA gene, was amplified by PCR using a set of primers, L892 and H2343. Cycle sequencing reactions were then performed using internal primer L1231 with ABI PRISM Dye Terminator Cycle Sequencing Ready Reaction (ABI, Perkin Elmer, Norwalk, CT, USA), in a model 377 automated DNA sequencer (ABI). Shown is the electrophoregram of V-43 with the A1555G mutation. b The presence of the A1555G mutation was examined in 24 other members of the family (IV-43, IV-45, IV-46, IV71, IV-73, IV-74, IV-77, IV-78, V-22, V-23, V-37, V-38, V-40, V-41, V42, V-46, V-47, V-48, V-49, V-50, V-51, V-52, V-55, and V-56) by PCR-RFLP using primer pair L1231 and H1782, and the PCR products were then digested with Alw26I restriction endonuclease. Shown are RFLP analyses of the PCR-amplified fragment from seven members of the family showing the homoplasmic presence of the mtDNA species carrying the $\mathrm{A} 1555 \mathrm{G}$ mutation. The results of the other 17 members showed similar homoplasmicity of the mtDNA

1999). Comparison of the sequencing data of EISi-V-43 and EISi-IV-45 revealed that their mtDNA are identical except for one nucleotide difference at nt $186(\mathrm{G}$ residue in $\mathrm{V}-43$ and $\mathrm{C}$ residue in IV-45). This observation indicates that the wife of IV-9 is still related to the large family, although perhaps rather remotely. Our finding is consistent with the sociocultural setting of the Balinese village, in that most of the family members have been living in a relatively isolated village for generations, and that distance consanguinity through intermarriage is common.

Sequence analysis of the Balinese family mtDNA that forms the background for the A1555G mutation

The penetrance of the A1555G mutation was found to be $28.9 \%$ (35 deaf members of 121 members older than 10 years of age carrying, or suspected to carry by virtue of the maternal inheritance, the mtDNA A1555G), with a maleto-female ratio of $21 / 14$, presumably as the result of the modulation of the expression of the A1555G mutation by nuclear modifiers (Guan et al. 1996). The influence of the overall mtDNA genetic background in the expression of the A1555G mtDNA mutation is less well understood. We have observed that the Southeast Asian mtDNAs are phyloge- netically distant from those of the Caucasians and Japanese (Sudoyo et al. 2002). To investigate the extent of the difference in the mtDNA sequence that forms the background for the A1555G mutation in our Balinese patients, as compared with those of the Caucasians and Japanese, we have sequenced the coding regions of the mtDNA of V-43 and IV-45, which, together with the D-loop sequence in the previous section, provide the complete mitochondrial genome sequence of the Balinese patients. In addition, a normal Balinese EIBal-034 was also included in this analysis. A total of 11 SNPs were observed in the protein-coding region of the mtDNA of EISi-V-43, and 5 others in the rRNA genes (Table 1). EISi-IV-45, a descendant of II-3, shows an identical set of 16 SNPs. Of the 16 SNPs in the coding region, 4 were found to be novel, not reported previously in Caucasians and Japanese, including 1 in the 16S rRNA gene (Table 1; shaded). Together with the mtDNA sequences of the normal Balinese EIBal-034, 20 SNPs not previously reported were identified; of these, 12 are in the coding regions of the mtDNA.

The sequences of the three Balinese mtDNAs described earlier are the first sets of the mitochondrial genome sequence reported for Southeast Asians. The comparison of the variations of the mtDNA sequence of our Balinese individuals with those of Caucasians and Japanese confirms the genetic distance of the Southeast Asian populations (data not shown).

Phenotypic expression of the A1555G mutation in fibroblast cell lines

We have investigated the defects in respiratory chain activity as a consequence of the A1555G mutation in fibroblast cell lines derived from symptomatic member EISi-IV-78 and asymptomatic member EISi-V-46. Microphotometric quantitative assessment of the well-characterized NADHtetrazolium reductase (NADH-TR) (Malik et al. 2000), a partial reaction of respiratory complex I, gave an indication of more than $10 \%$ reduction of the NADH-TR activities in both symptomatic EISi-IV-78 and asymptomatic EISi-V-46 fibroblast lines when compared with a normal cell line (EIN-2-95; data not shown). The respiratory complex I activity, therefore, was more precisely determined by measuring the NADH-cytochrome $c$ oxidoreductase activity (complex I + III), to examine the extent of its reduction.

The NADH-cytochrome $c$ oxidoreductase activity of mitochondria isolated from fibroblasts of the symptomatic member EISi-IV-78 showed a significant $(35 \% ; P<0.005)$ reduction of activity when compared with that of the normal cell line EIN-2-95. Despite the significant reduction of NADH-cytochrome $c$ oxidoreductase activity, succinatecytochrome $c$ reductase activity (Table 2) did not show any significant reduction. Thus, the lower NADH-cytochrome $c$ oxidoreductase activity in the symptomatic member is mainly due to a defective respiratory complex I (NADHubiquinone oxidoreductase). 
Table 1. SNPs in the MtDNA of the Balinese family carrying the A1555G mutation

D-loop region

\begin{tabular}{|c|c|c|c|c|c|c|c|c|c|c|c|c|c|c|c|c|c|c|c|}
\hline rCRS & $\underset{\curvearrowright}{\circledR}$ & 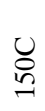 & $\begin{array}{l}0 \\
\infty \\
-\infty\end{array}$ & 향 & $\begin{array}{l}\mathbb{\overbrace} \\
\text { ते }\end{array}$ & $\underset{\vec{F}}{\stackrel{U}{f}}$ & 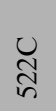 & $\begin{array}{l}\mathbb{N} \\
\text { ஸn }\end{array}$ & $\frac{5}{8}$ & 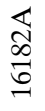 & $\begin{array}{l}\mathbb{\infty} \\
\infty \\
\approx \\
-\end{array}$ & $\begin{array}{l}5 \\
\infty \\
-6 \\
-1\end{array}$ & $\frac{E}{\stackrel{\sigma}{\sigma}}$ & $\begin{array}{l}\text { U } \\
\text { బ } \\
0\end{array}$ & $\begin{array}{l}\underset{+}{J} \\
\underset{\sigma}{-}\end{array}$ & $\begin{array}{l}\text { ठ } \\
\text { స్ర }\end{array}$ & 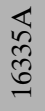 & 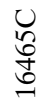 & $\frac{5}{\sqrt[5]{2}}$ \\
\hline EISi-V-43 & G & $\mathrm{T}$ & $\mathrm{G}$ & $\mathrm{C}$ & G & . & & & $\mathrm{C}$ & $\mathrm{C}$ & $\mathrm{C}$ & $\mathrm{C}$ & $\mathrm{C}$ & . & A & . & G & & $\mathrm{C}$ \\
\hline EISi-IV-45 & G & $\mathrm{T}$ & ${ }^{\circ}$ & $\mathrm{C}$ & G & & & & $\mathrm{C}$ & $\mathrm{C}$ & $\mathrm{C}$ & $\mathrm{C}$ & $\mathrm{C}$ & & A & & G & & $\mathrm{C}$ \\
\hline EIBal-034 & G & . & . & $\mathrm{C}$ & G & G & del & del & . & . & . & . & . & $\mathrm{T}$ & & $\mathrm{T}$ & . & $\mathrm{T}$ & \\
\hline
\end{tabular}

tRNAs and rRNAs

\begin{tabular}{|c|c|c|c|c|c|c|c|c|c|}
\hline \multirow[b]{2}{*}{ Gene } & \multicolumn{2}{|c|}{$\mathrm{F}$} & \multicolumn{6}{|c|}{$12 \mathrm{~S}$} & \multirow{2}{*}{$\begin{array}{l}16 \mathrm{~S} \\
\cup \\
2 \\
\infty \\
-1\end{array}$} \\
\hline & $\begin{array}{l}0 \\
\infty \\
\infty\end{array}$ & ॄै & $\begin{array}{l}\text { ڤু } \\
\text { }\end{array}$ & $\begin{array}{l}\text { ஜे } \\
\text { }\end{array}$ & 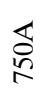 & 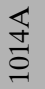 & $\begin{array}{l}\mathbb{\infty} \\
\underset{\Xi}{ \pm}\end{array}$ & $\begin{array}{l}\varangle \\
\stackrel{n}{n} \\
n\end{array}$ & \\
\hline rCRS & & & & & & & & & \\
\hline EISi-V-43 & . & & & A & G & . & G & G & $\mathrm{T}$ \\
\hline EISi-IV-45 & & & & A & G & & G & G & $\mathrm{T}$ \\
\hline EIBal-034 & $\mathrm{C}$ & A & $\mathrm{T}$ & . & G & $\mathrm{T}$ & G & . & \\
\hline
\end{tabular}

Protein coding

\begin{tabular}{|c|c|c|c|c|c|c|c|c|c|c|c|c|c|c|c|c|}
\hline \multirow{2}{*}{$\begin{array}{l}\text { Gene } \\
\\
\text { rCRS }\end{array}$} & \multicolumn{3}{|c|}{ ND1 } & \multicolumn{2}{|c|}{ ND2 } & \multicolumn{2}{|c|}{ COI } & $\begin{array}{c}\text { ATP } \\
6\end{array}$ & \multicolumn{2}{|c|}{ ND4 } & \multicolumn{3}{|c|}{ ND5 } & \multicolumn{3}{|c|}{ Cyt b } \\
\hline & $\frac{u}{\stackrel{0}{a}}$ & 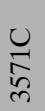 & $\begin{array}{l}\cup \\
\stackrel{n}{\forall} \\
\frac{7}{\forall}\end{array}$ & 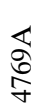 & 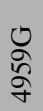 & $\begin{array}{l}0 \\
\frac{\infty}{6} \\
\text { don }\end{array}$ & 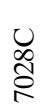 & $\begin{array}{l}\mathbb{8} \\
\mathbb{\infty} \\
\infty \\
\infty\end{array}$ & $\begin{array}{l}\sqrt{n} \\
m \\
\stackrel{m}{=}\end{array}$ & $\begin{array}{l}\circlearrowright \\
\stackrel{\Xi}{\Xi} \\
=\end{array}$ & 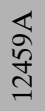 & 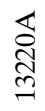 & $\begin{array}{l}\cup \\
\infty \\
\infty \\
\text { ֻ } \\
\sim\end{array}$ & $\begin{array}{l}0 \\
\stackrel{0}{ } \\
\infty \\
n \\
n\end{array}$ & $\begin{array}{l}\overleftarrow{N} \\
\widetilde{N} \\
\text { ñ }\end{array}$ & $\begin{array}{l}0 \\
\text { Oे } \\
n \\
n\end{array}$ \\
\hline EISi-V-43 & $\mathrm{T}$ & $\mathrm{T}$ & & G & . & $\mathrm{C}$ & $\mathrm{T}$ & G & $\cdot$ & A & & G & $\cdot$ & A & $\mathrm{G}$ & A \\
\hline EISi-IV-45 & $\mathrm{T}$ & $\mathrm{T}$ & & G & & $\mathrm{C}$ & $\mathrm{T}$ & G & & A & & G & & A & G & A \\
\hline EIBal-034 & & . & A & G & $\mathrm{C}$ & & . & G & $\mathrm{C}$ & A & G & . & A & . & G & . \\
\hline
\end{tabular}

SNPs, Single-nucleotide polymorphisms; rCRS, revised Cambridge reference sequence (Anderson et al. 1981; Andrews et al. 1999)

Table 2. Respiratory enzyme activities measured in mitochondria isolated from fibroblast cells with the A1555G MtDNA mutation

\begin{tabular}{lll}
\hline Cell line & $\begin{array}{l}\text { NADH-cyt } c \text { reductase } \\
\text { (nmol cytochrome } c \\
\text { /min/mg protein) }\end{array}$ & $\begin{array}{l}\text { Succinate-cyt } c \text { reductase } \\
\text { (nmol cytochrome } c \\
\text { /min/mg protein) }\end{array}$ \\
\hline EIN-2-95 & $207.7 \pm 24.5$ & $30.5 \pm 8.2$ \\
EISi-IV-78 (symptomatic) & $134.4 \pm 15.5$ & $37.5 \pm 0.7$ \\
EISi-V-46 (asymptomatic) & $181.6 \pm 22.3$ & $28.0 \pm 2.8$ \\
\hline
\end{tabular}

\section{Discussion}

The results of the study reported here are of interest for several reasons. First, we have been able to demonstrate that the unusual pattern of inheritance observed in the $\mathrm{Ba}$ linese family is the result of multiple entries of the causal mtDNA A1555G mutation into the family. These multiple entries are most likely due to distant consanguinity not known to the family, perhaps more common in the sociocultural setting of island Southeast Asian villages, a fact that is important to recognize in future studies.

The present study is also of importance because it reports the first complete mtDNA genome sequence from Southeast Asia, which confirms the genetic distance of
Southeast Asian populations from those of Caucasians and Japanese. A reduction of respiratory complex I activity was observed, consistent with the earlier suggestion from the study of an Arab-Israeli family that the mtDNA A1555G mutation results in a defective respiratory enzyme complex (Guan et al. 1996). The reduction in respiratory complex I activity observed (35\% in symptomatic and $13 \%$ in asymptomatic members, respectively) is not as severe as that reported for the Arab-Israeli pedigree [56\% and 50\% in symptomatic and asymptomatic members (Guan et al. 1996)], but it is not clear as yet whether the less severe reduction is due to the difference in the mtDNA background. The different degree of reduction in respiratory enzyme activity observed in symptomatic and asymptomatic members is consistent with the observation of Guan et 
al. (1996), which in the latter has been shown to be due to as yet unidentified nuclear modifiers (Guan et al. 2001). Such nuclear factors could also contribute to the variation in respiratory enzyme activity observed in patients of different ethnic backgrounds.

Finally, the demonstration that the mtDNA A1555G mutation exists in island Southeast Asians is of significance. This is particularly so because, in contrast, the mtDNA A3243G mutation, which is another major mtDNA mutation underlying sensorineural deafness [with or without diabetes mellitus (Manouvrier et al. 1995; Kadowaki et al. 1994; van den Ouweland et al. 1992)], has not been found in Southeast Asians, despite the screening of more than 1500 Indonesian patients with type II diabetes mellitus (Sudoyo H, Pranoto A, Marzuki S, unpublished). In Japan, the A3243G mutation accounts for $0.9 \%-2 \%$ of diabetic patients (Kadowaki et al. 1994, 1995), $1.74 \%$ of sensorineural deafness patients (Nagata et al. 2001), and as many as $50 \%$ of patients with sensorineural deafness and diabetes mellitus (Nagata et al. 2001). The mtDNA A1555G mutation is an important contributor to sensorineural deafness in the Japanese population $[3 \%$ of patients with sensorineural deafness carry the A1555G mutation (Usami et al. 1999)]. It is thus important to determine the contribution of this mutation as the cause of sensorineural deafness in Southeast Asia.

Acknowledgments We thank all the family members that have participated in the present study. We would like to thank Dr. Helena Suryadi for her expert assistance in the fieldwork, and Ms. Neny Sitorus for tissue culture work. This work was supported by grants from PT Krakatau Steel and PT Inti through the Agency for Strategic Industries (Indonesia) and by a generous Development Fund from the National Development Planning Agency (BAPPENAS) of the Republic of Indonesia

\section{References}

Anderson S, Bankier AT, Barrell BG, de Bruijn MH, Coulson AR, Drouin J, Eperon IC, Nierlich DP, Roe BA, Sanger F, Schreier PH, Smith AJ, Staden R, Young IG (1981) Sequence and organization of the human mitochondrial genome. Nature 290:457-465

Andrews RM, Kubacka I, Chinnery PF, Lightowlers RN, Turnbull DM, Howell N (1999) Reanalysis and revision of the Cambridge reference sequence for human mitochondrial DNA. Nat Genet 23:147

Byrne E, Trounce I, Dennet X, Gilligan B, Morley JB, Marzuki S (1988) Progression from MERRF to MELAS phenotype in a patient with combined respiratory complex I and IV deficiencies. J Neurol Sci 88:327-337

De Stasio EA, Moazed D, Noller HF, Dahlberg AE (1989) Mutations in $16 \mathrm{~S}$ ribosomal RNA disrupt antibiotic-RNA interactions. EMBO J 8:1213-1216

Estivill X, Govea N, Barcelo E, Badenas C, Romero E, Moral L, Scozzri R, D’Urbano L, Zeviani M, Torroni A (1998) Familial progressive sensorineural deafness is mainly due to the mtDNA A1555G mutation and is enhanced by treatment of aminoglycosides. Am J Hum Genet 62:27-35

Etzold T, Fritz CC, Schell J, Scherier PH (1987) A point mutation in the chloroplast $16 \mathrm{~S}$ rRNA are streptomycin resistant. EMBO J 219:343-346

Guan MX, Fischel-Ghodsian N, Attardi G (1996) Biochemical evidence for nuclear gene involvement in phenotype of non-syndromic deafness associated with mitochondrial $12 \mathrm{~S}$ rRNA mutation. Hum Mol Genet 5:963-971

Guan MX, Fischel-Ghodsian N, Attardi G (2001) Nuclear background determines biochemical phenotype in the deafness-associated mitochondrial 12S rRNA mutation. Hum Mol Genet 10:573-580
Kadowaki T, Kadowaki H, Mori Y, Tobe K, Sakuta R, Suzuki Y, Tanabe Y, Sakura H, Awata T, Goto Y, Hayakaua T, Matsuoka K, Kawamori R, Kamada T, Horai S, Nonaka I, Hagura R, Akanuma Y, Yazaki Y (1994) A subtype of diabetes mellitus associated with a mutation of mitochondrial DNA. N Engl J Med 330:962-968

Kadowaki T, Sakura H, Otabe S, Yasuda K, Kadowaki H, Mori Y, Hagura R, Akanuma Y, Yazaki Y (1995) A subtype of diabetes mellitus associated with a mutation in the mitochondrial gene. Muscle Nerve 3:S137-S141

Lertrit P, Noer AS, Byrne E, Marzuki S (1992) Tissue segregation of a heteroplasmic mtDNA mutation in MERRF (myoclonic epilepsy with ragged red fibers) encephalomyopathy. Hum Genet 90:251-254

Malik S, Sudoyo H, Marzuki S (2000) Microphotometric analysis of NADH-tetrazolium reductase deficiency in fibroblasts of patients with Leber's hereditary optic neuropathy. J Inherit Metab Dis 23:730-744

Malik S, Sudoyo H, Pramoonjago P, Suryadi H, Sukarna T, Njunting M, Sahiratmadja E, Marzuki S (2002) Nuclear mitochondrial interplay in the modulation of the homopolymeric tract length heteroplasmy in the control (D-loop) region of the mitochondrial DNA. Hum Genet 110:402-411

Manouvrier S, Rotig A, Hannebique G, Gheerbrandt JD, RoyerLegrain G, Munnich A, Parent M, Grunfeld JP, Largilliere C, Lombes A (1995) Point mutation of the mitochondrial tRNA(Leu) gene (A $3243 \mathrm{G}$ ) in maternally inherited hypertrophic cardiomyopathy, diabetes mellitus, renal failure and sensorineural deafness. J Med Genet 32:654-656

Marzuki S, Noer AS, Lertrit P, Thyagarajan D, Kapsa R, Utthanaphol P, Byrne E (1991) Normal variants of human mitochondrial DNA and translation products: the building of a reference data base. Hum Genet 88:139-145

Matthijs G, Claes S, Longo-Mbenza B, Cassiman JJ (1996) Nonsyndromic deafness associated with a mutation and a polymorphism in the mitochondrial $12 \mathrm{~S}$ ribosomal RNA gene in a large Zairean pedigree. Eur J Hum Genet 4:46-51

Montandon PE, Wagner R, Stutz E (1986) E. coli ribosomes with a C912 to U base change in the 16S rRNA are streptomycin resistant. EMBO J 5:3705-3708

Nagata H, Kumahara K, Tomemori T, Arimoto Y, Isoyama K, Yoshida K, Konno A (2001) Frequency and clinical features of patients with sensorineural hearing loss associated with the A3243G mutation of the mitochondrial DNA in otorhinolaryngic clinics. J Hum Genet 46:595-599

Pandya A, Xia X, Radnaabazar J, Batsuuri J, Dangaansuren B, Odgerel D, Fischel-Ghodsian N, Nance WE (1997) Mutation in the mitochondrial 12S rRNA gene in two families from Mongolia with matrilineal aminoglycoside ototoxicity. J Med Genet 34:169-172

Prezant TR, Agapian JV, Bohlman MC, Bu X, Oztas S, Qiu W, Arnos KS, Cortopassi GA, Jaber L, Rotter JI, Shohat M, Fischel-Ghodsian N (1993) Mitochondrial ribosomal RNA mutation associated with both antibiotic-induced and non-syndromic deafness. Nat Genet 4:289-294

Sudoyo H, Suryadi H, Lertrit P, Pramoonjago P, Lyrawati D, Marzuki S (2002) Asian specific mtDNA backgrounds associated with the primary G11778A mutation of Leber's hereditary optic neuropathy. J Hum Genet 47:594-604

Torroni A, Schurr TG, Cabell MF, Brown MD, Neel JV, Larsen M, Smith DG, Vullo CM, Wallace DC (1993) Asian affinities and continental radiation of the four founding native American mtDNAs. Am J Hum Genet 53:563-590

Trounce IA, Kim YL, Jun AS, Wallace DC (1996) Assessment of mitochondrial oxidative phosphorylation in patient muscle biopsies, lymphoblasts, and transmitochondrial cell lines. Methods Enzymol 264:484-509

Usami S, Abe S, Kasai M, Shinkawa H, Moeller B, Kenyon J, Kimberling WJ (1997) Genetic and clinical features of sensorineural hearing loss associated with the 1555 mitochondrial mutation. Laryngoscope 107:483-490

Usami S, Abe S, Kasai M, Shinkawa H, Inoue Y, Yamaguchi T (1999) Rapid mass screening method and counseling for the 1555A-G mitochondrial mutation. J Hum Genet 44:304-307

van den Ouweland JM, Lemkes HH, Ruitenbeek W, Sandkuijl LA, de Vijlder MF, Struyvenberg PA, van de Kamp JJ, Maassen JA (1992) Mutation in mitochondrial tRNA(Leu)(UUR) gene in a large pedigree with maternally transmitted type II diabetes mellitus and deafness. Nat Genet 1:368-371 